\title{
Estimation of Avoidable Yield Loss Due to Sucking Pest Complex in Blackgram
}

\author{
Malreddy Radhika* and Chinthakindi Narendra Reddy
}

S. B. Pally (Vill), Kothur (Man), Ranga Reddy (Dist), Telangana (State), Pin-509225, Post

(Siddapur), India

*Corresponding author

\section{A B S T R A C T}

\begin{tabular}{|c|}
\hline Keywords \\
\hline $\begin{array}{l}\text { Estimation, Avoidable } \\
\text { yield loss, Sucking pest } \\
\text { complex, Blackgram }\end{array}$ \\
\hline Article Info \\
\hline $\begin{array}{l}\text { Accepted: } \\
18 \text { April } 2018 \\
\text { Available Online: } \\
10 \text { May } 2018\end{array}$ \\
\hline
\end{tabular}

\begin{abstract}
An experiment was laid out with two treatments viz., unprotected and protected plot with plot size of $100 \mathrm{~m}^{2}$ each and further each treatment was divided into 13 quadrates with 30 X $10 \mathrm{~cm}$ spacing in Randomised Block Design (RBD). Results revealed that the avoidable reduction in plant height, number of branches per plant, pods per plant, number of seeds per pod due to insecticides application is $19.14,19.78,20.70$ and 17.80 per cent respectively and a significantly higher yield was obtained in protected plots i.e. $1028 \mathrm{~kg}$ $\mathrm{ha}^{-1}$, while, comparatively low yield i.e. $759 \mathrm{~kg} \mathrm{ha}^{-1}$ was recorded from unprotected plots. The yield increased in protected plots over unprotected was $269 \mathrm{~kg} \mathrm{ha}^{-1}$ i.e. 35.44 per cent. The avoidable yield loss was 26.16 per cent by spraying of insecticides i.e. monocrotophos $36 \%$ SC and fipronil 5\% SC at ten days intervals against sucking pests viz., whiteflies, thrips, aphids and leafhoppers in blackgram.
\end{abstract}

\section{Introduction}

Blackgram, Vigna mungo (Linn.) Hepper, also known as urd bean, mash, mungo bean, mashkalai black mapte etc., belongs to the family Leguminosae; sub family Papilionaceae. It is the fourth most important short-duration pulse crop grown in India due to its nutritional and industrial values. Seeds of blackgram are very rich in protein (24 per cent) and phosphoric acid (385 mg100 g $\mathrm{g}^{-1}$ ) among pulses. Blackgram is used in different food items all over the world. Its green fodder is very nutritive and specially fed to milch cattle (Jeswani and Baldev, 1990). The important blackgram growing states are Maharashtra, Karnataka, Andhra Pradesh,
Telangana, Tamil Nadu, Madhya Pradesh and West Bengal

Eleven insect pests were recorded in blackgram, out of which sap feeders consisted of whitefly (Bemisia tabaci), jassid (Empoasca spp.) green leaf hopper (Nephotettix spp.) and flower thrips (Caliothrips spp.) caused severe damage to the crop (Chandra and Rajak, 2004). The avoidable losses due to pest complex on different varieties of urdbean ranged from 15.62 to 30.96 per cent with an average of 24.03 per cent. Among all the sucking pests whitefly, a potential vector of mungbean yellow mosaic virus (MYMV), alone can cause damage upto 30-70 per cent 
(Duraimurugan and Tyagi, 2014). Estimation of avoidable yield losses makes one to understand the damage levels caused by the insect pests and allows one to take preventive measures without causing economic damage.

\section{Materials and Methods}

A field experiment was carried out on "Studies on avoidable yield loss due to sucking pest complex in blackgram Vigna mungo (Linn.) Hepper." during rabi2017-18 at Students farm, College of Agriculture, Rajendranagar, Hyderabad. To estimate the losses caused by sucking pest complex in blackgram, an experiment was laid out with two treatments viz., unprotected and protected plot with plot size of $100 \mathrm{~m}^{2}$ each and further each treatment was divided into 13 quadrates with $30 \times 10 \mathrm{~cm}$ spacing in Randomised Block Design (RBD). Unprotected plots were kept free from insecticides, whereas, protected plots were kept free from pest damage through application of pesticides as per package of practices recommended by PJTSAU at regular intervals throughout the crop growth period

Fipronil $5 \% \quad \mathrm{SC}$ at $1 \mathrm{ml} \quad \mathrm{lit}^{-1}$ and monocrotophos $36 \%$ SC at $1.6 \mathrm{ml} \mathrm{lit}^{-1}$ insecticides were sprayed starting from flower intiation to pod maturity at ten days interval on rotation basis in the protected plots while in the unprotected plots, plant protection measures were not taken up.Data on plant height, number of branches at 65 DAS, number of pods per plant, number of seeds per pod and seed yield were recorded

Yield of blackgram received from protected plots and unprotected plots were recorded separately at harvest. The yield increase in protected plots over the unprotected (control) and avoidable yield loss was worked out by using the following formula given by Pradhan (1969).
Yield increased $(\%)=\frac{\mathrm{T}-\mathrm{C}}{\mathrm{C}} \times 100$

Avoidable yield loss $(\%)=\frac{\mathrm{T}-\mathrm{C}}{\mathrm{T}} \times 100$

Where,

$\mathrm{T}=$ Yield from treated (protected) plots $(\mathrm{Kg}$ $\mathrm{ha}^{-1}$ )

$\mathrm{C}=$ Yield from control (untreated) plots $(\mathrm{Kg}$ $\mathrm{ha}^{-1}$ )

The significant difference between two treatments protected and unprotected plots were worked out by using two sample t-test for each parameter viz., plant height, number of branches at 65 DAS, number of pods per plant, number of seeds per pod and seed yield.

\section{Results and Discussion}

\section{Plant height (cm)}

The results presented in the table 1 and figure 1 illustrated that there was a significant difference in plant heights of blackgram between protected and unprotected plants. The plant height in protected plots ranged from 29 to $34 \mathrm{~cm}$ with a mean of $31.77 \mathrm{~cm}$ as against 24 to $28 \mathrm{~cm}$ with a mean of 25.69 in unprotected plots. The difference in plant height due to spraying of insecticides is 19.14 per cent.

\section{Number of branches per plant}

The incidence of sucking pests in blackgram significantly affected the number of branches per plant in unprotected plots (Table 2) and figure 2 during rabi 2017-18. It was observed that in protected plots number of branches per plant ranged from 5 to 6 with a mean of 5.46 branches per plant, whereas in unprotected plots the range was between 4 and 5 with a mean of 4.38 branches per plant. The difference in number of branches per plant due to adoption of insecticidal spraying was 19.78 per cent. 
Table.1 Effect of sucking pests infestation on plant height $(\mathrm{cm})$ in rabi blackgram during 2017-18

\begin{tabular}{|c|c|c|c|}
\hline \multirow{2}{*}{ S. No } & \multicolumn{2}{|c|}{ Plant height $(\mathbf{c m})$} & A voidable loss \\
& Protected $\left(\mathbf{T}_{\mathbf{1}}\right)$ & Unprotected & $\left.\mathbf{( T}_{\mathbf{2}}\right)$ \\
\hline $\mathbf{1}$ & 31.00 & 26.00 & 16.13 \\
\hline $\mathbf{2}$ & 32.00 & 25.00 & 21.88 \\
\hline $\mathbf{3}$ & 33.00 & 26.00 & 21.21 \\
\hline $\mathbf{4}$ & 31.00 & 27.00 & 12.90 \\
\hline $\mathbf{5}$ & 30.00 & 25.00 & 16.67 \\
\hline $\mathbf{6}$ & 31.00 & 26.00 & 16.13 \\
\hline $\mathbf{7}$ & 32.00 & 27.00 & 15.63 \\
\hline $\mathbf{8}$ & 33.00 & 25.00 & 24.24 \\
\hline $\mathbf{9}$ & 34.00 & 24.00 & 29.42 \\
\hline $\mathbf{1 0}$ & 34.00 & 24.00 & 29.42 \\
\hline $\mathbf{1 1}$ & 30.00 & 25.00 & 16.67 \\
\hline $\mathbf{1 2}$ & 29.00 & 26.00 & 10.34 \\
\hline $\mathbf{1 3}$ & 33.00 & 28.00 & 15.15 \\
\hline Mean & 31.77 & 25.69 & 19.14 \\
\hline
\end{tabular}

$\mathrm{t}$ - calculated at $5 \%$ level of significance $=11.06$

$\mathrm{t}-$ tabulated at $5 \%$ level of significance $=2.07$

Table.2 Effect of sucking pests infestation on number of branches per plant in rabi blackgram during 2017-18

\begin{tabular}{|c|}
\hline S. No \\
\hline 1 \\
\hline 2 \\
\hline 3 \\
\hline 4 \\
\hline 5 \\
\hline 6 \\
\hline 7 \\
\hline 8 \\
\hline 9 \\
\hline 10 \\
\hline 11 \\
\hline 12 \\
\hline 13 \\
\hline Mean
\end{tabular}

\begin{tabular}{|r|}
\hline Num \\
\hline Protected \\
\hline 5.00 \\
\hline 6.00 \\
\hline 5.00 \\
\hline 6.00 \\
\hline 6.00 \\
\hline 6.00 \\
\hline 5.00 \\
\hline 5.00 \\
\hline 5.00 \\
\hline 5.00 \\
6.00 \\
\hline 6.00 \\
5.00 \\
\hline 5.46 \\
\hline
\end{tabular}

Number of branches per plant

Unprotected $\left(\mathbf{T}_{2}\right)$

4.00

5.00

4.00

5.00

5.00

5.00

4.00

4.00

4.00

4.00

5.00

4.00

4.00

4.38
A voidable loss

$(\%)$

20.00

16.67

20.00

16.67

16.67

16.67

20.00

20.00

20.00

20.00

16.67

33.33

20.00

19.78

$\mathrm{t}$ - calculated at $5 \%$ level of significance $=4.67$

$\mathrm{t}$ - tabulated at $5 \%$ level of significance $=2.07$ 
Table.3 Effect of sucking pests infestation on number of pods per plant in rabi blackgram during 2017-18

\begin{tabular}{|c|c|c|c|}
\hline \multirow{2}{*}{ S. No } & \multicolumn{2}{|c|}{ Number of pods per plant } & Avoidable loss (\%) \\
\hline $\mathbf{1}$ & Protected $\left(\mathbf{T}_{\mathbf{1}}\right)$ & Unprotected $\left.\mathbf{( T}_{\mathbf{2}}\right)$ & \\
\hline $\mathbf{2}$ & 40.00 & 26.00 & 35.00 \\
\hline $\mathbf{3}$ & 30.00 & 26.00 & 13.33 \\
\hline $\mathbf{4}$ & 37.00 & 36.00 & 2.70 \\
\hline $\mathbf{5}$ & 40.00 & 38.00 & 5.00 \\
\hline $\mathbf{6}$ & 38.00 & 22.00 & 42.10 \\
\hline $\mathbf{7}$ & 35.00 & 26.00 & 25.71 \\
\hline $\mathbf{8}$ & 36.00 & 32.00 & 11.11 \\
\hline $\mathbf{9}$ & 38.00 & 24.00 & 36.84 \\
\hline 10 & 38.00 & 36.00 & 5.20 \\
\hline 11 & 30.00 & 26.00 & 13.33 \\
\hline 12 & 32.00 & 28.00 & 12.50 \\
\hline Mean & 30.00 & 20.00 & 33.33 \\
\hline
\end{tabular}

$\mathrm{t}$ - calculated at $5 \%$ level of significance $=3.90$

$\mathrm{t}$ - tabulated at $5 \%$ level of significance $=2.07$

Table.4 Effect of sucking pests infestation on number of seeds per pod in rabi blackgram during 2017-18

\begin{tabular}{|c|c|c|c|}
\hline S. No & \multicolumn{2}{|c|}{ Number of seeds per pod } & Avoidable loss (\%) \\
\hline 1 & Protected $\left(\mathbf{T}_{\mathbf{1}}\right)$ & Unprotected $\left.\mathbf{( T}_{\mathbf{2}}\right)$ & \\
\hline $\mathbf{1}$ & 6.00 & 5.00 & 16.67 \\
\hline $\mathbf{3}$ & 7.00 & 6.00 & 14.29 \\
\hline $\mathbf{4}$ & 6.00 & 5.00 & 16.67 \\
\hline $\mathbf{5}$ & 7.00 & 6.00 & 14.29 \\
\hline $\mathbf{6}$ & 8.00 & 6.00 & 25.00 \\
\hline 7 & 5.00 & 4.00 & 20.00 \\
\hline $\mathbf{8}$ & 6.00 & 5.00 & 16.67 \\
\hline $\mathbf{9}$ & 7.00 & 6.00 & 14.29 \\
\hline $\mathbf{1 0}$ & 7.00 & 6.00 & 14.29 \\
\hline $\mathbf{1 1}$ & 7.00 & 6.00 & 14.29 \\
\hline $\mathbf{1 2}$ & 7.00 & 5.00 & 28.57 \\
\hline $\mathbf{1 3}$ & 5.00 & 4.00 & 20.00 \\
\hline Mean & 6.00 & 5.00 & 16.67 \\
\hline
\end{tabular}

$\mathrm{t}$ - calculated at $5 \%$ level of significance $=3.60$

$\mathrm{t}$ - tabulated at $5 \%$ level of significance $=2.07$ 
Table.5 Estimation of yield losses caused by sucking pests in blackgram during rabi 2017-18

\begin{tabular}{|c|c|c|c|c|c|}
\hline S. no & Treatment & $\begin{array}{c}\text { Pod Yield } \\
\left(\mathrm{kg} \mathrm{ha}^{-1}\right)\end{array}$ & $\begin{array}{c}\text { Yield increased } \\
\text { over control } \\
\left(\mathrm{kg} \mathrm{ha}^{-1}\right)\end{array}$ & $\begin{array}{c}\text { Yield increased } \\
(\%)\end{array}$ & $\begin{array}{c}\text { A voidable } \\
\text { yield loss (\%) }\end{array}$ \\
\hline T1 & Protected & 1028 & 269.00 & 35.44 & 26.16 \\
\hline T2 & Unprotected & 759 & - & - & - \\
\hline & C.D. & 0.822 & - & - & - \\
\hline SE(m) & 0.264 & - & - & - \\
\hline SE(d) & 0.373 & - & - & - \\
\hline C.V. & 12.102 & - & - & - \\
\hline
\end{tabular}

Fig.1 Plant height in protected and unprotected plots during rabi 2017-18

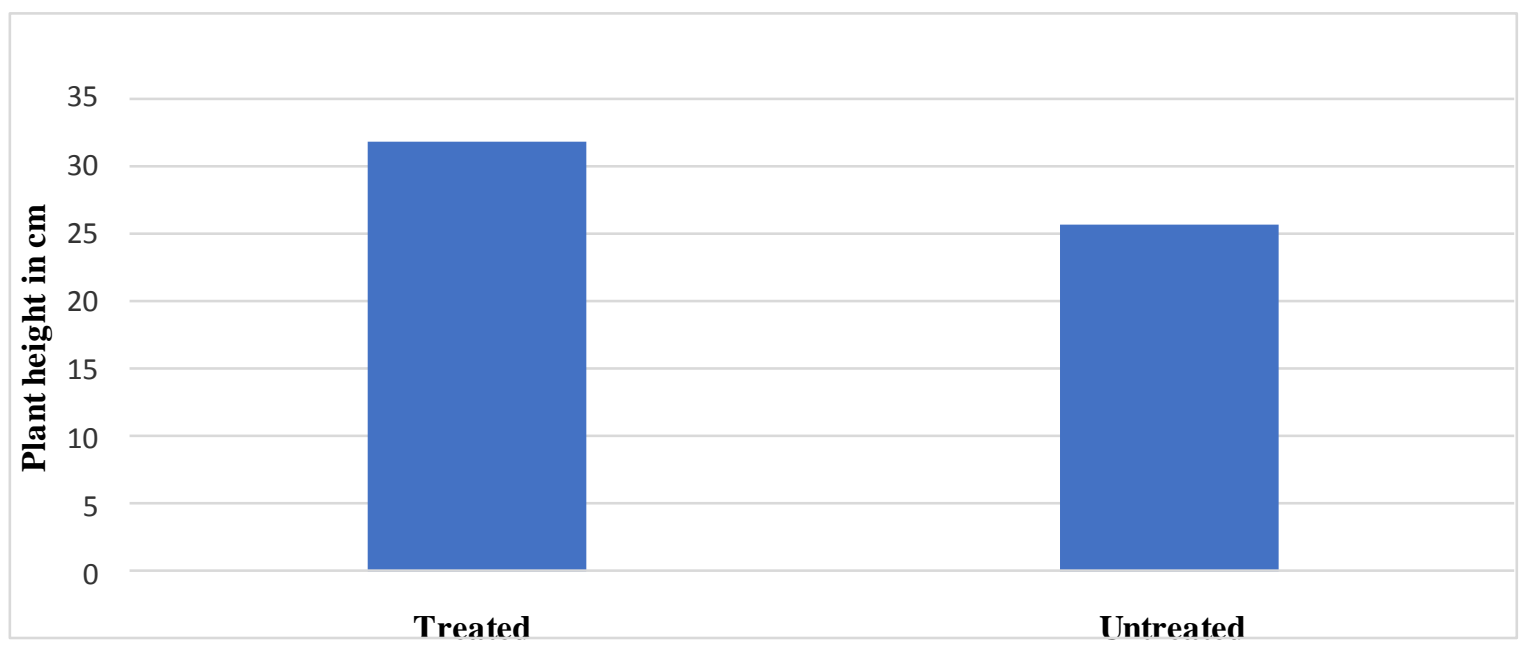

Fig.2 Number of branches in protected and unprotected plots during rabi 2017-18

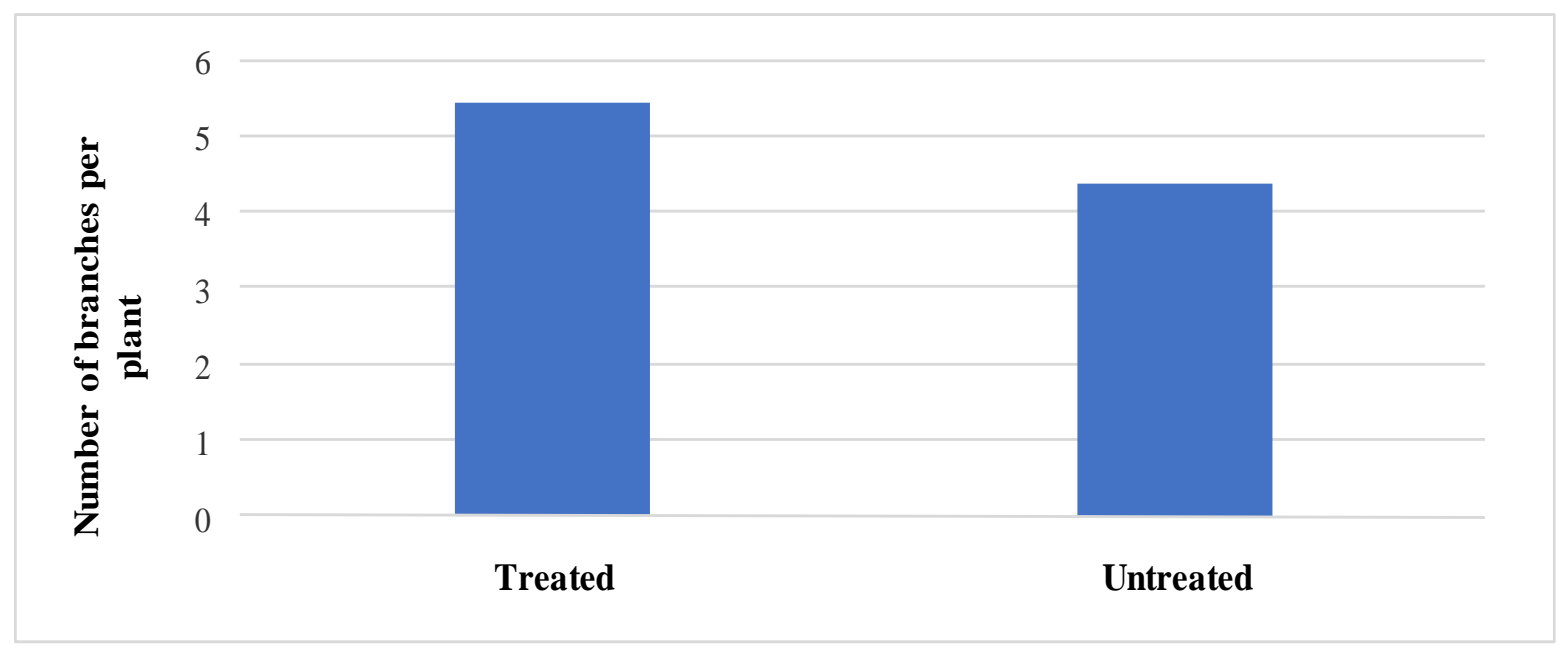


Fig.3 Number of pods per plant in protected and unprotected plots during rabi 2017-18

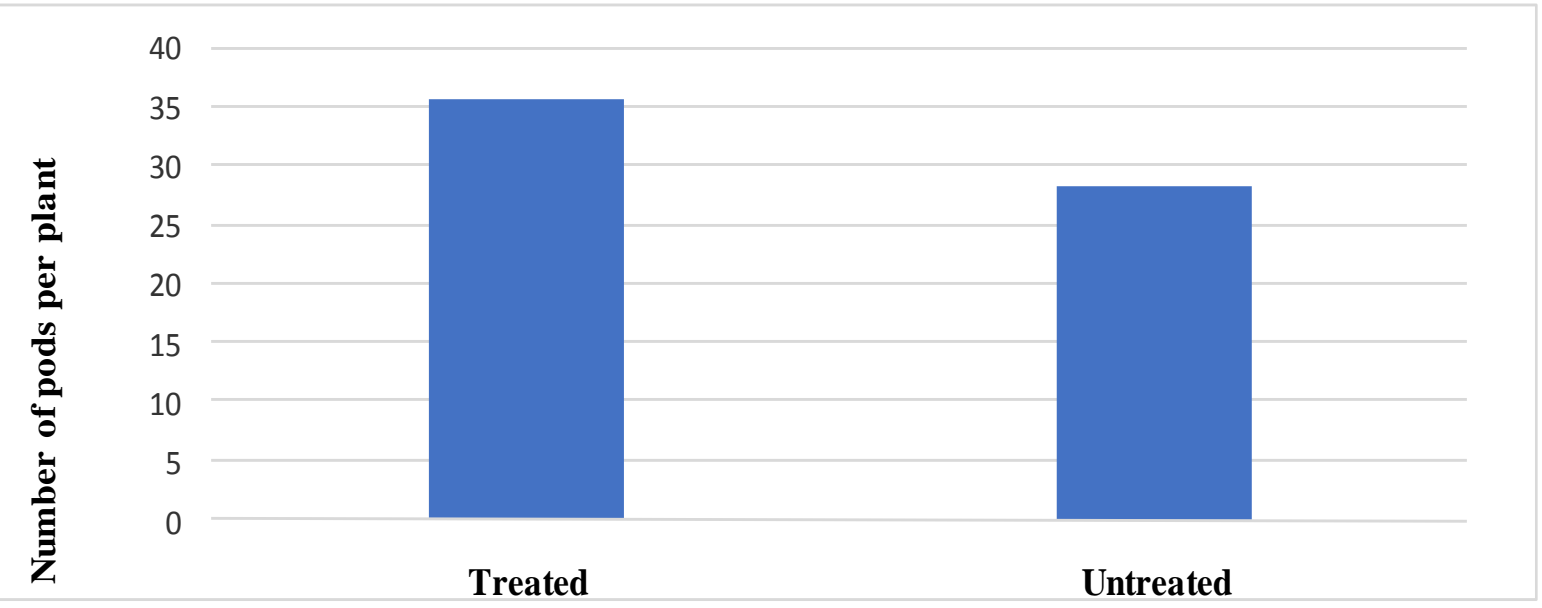

Fig.4 Number of seeds per pod in protected and unprotected plots during rabi 2017-18

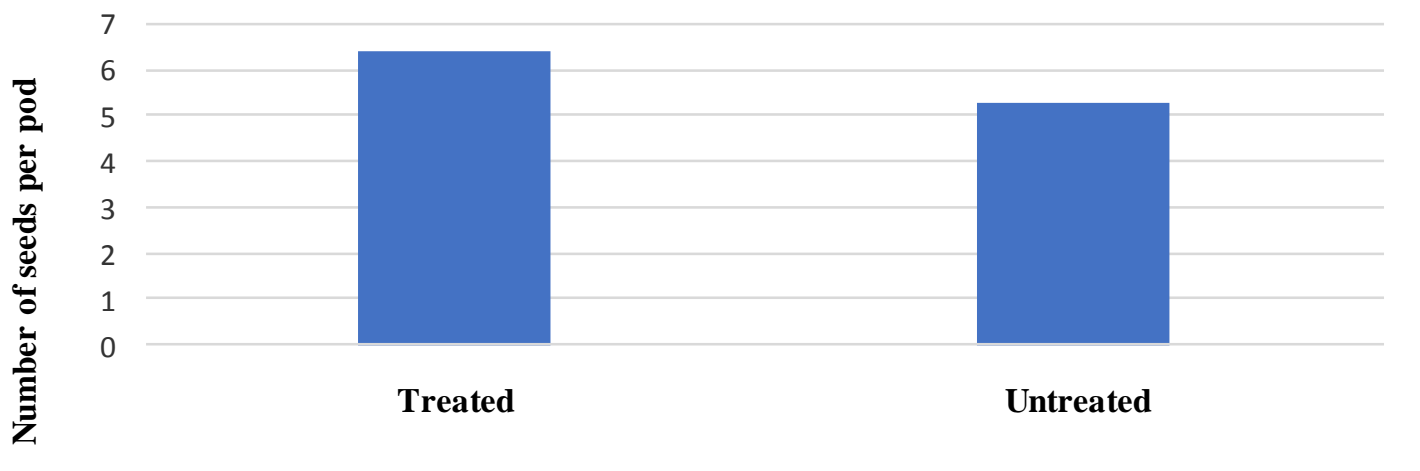

Fig.5 Yield of blackgram in treated and untreated plots during rabi 2017-18

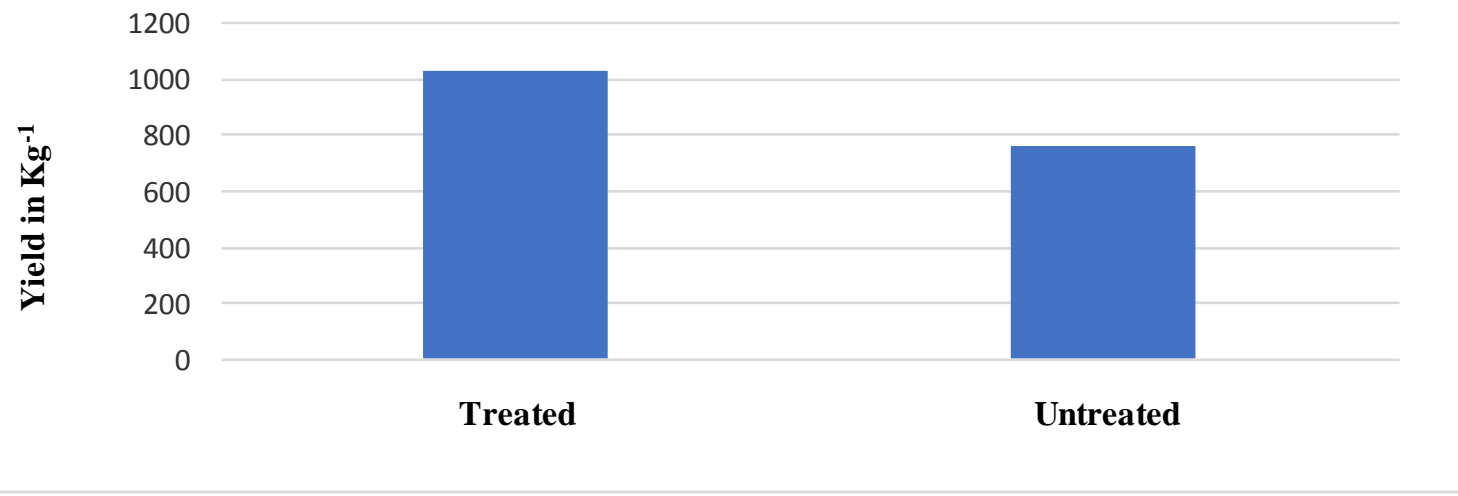




\section{Number of pods per plant}

The results presented in the table 3 and figure 3 showed that there was a significant difference between number of pods per plant in protected and unprotected plots during rabi 2017-18.

It was observed that in unprotected plots number of pods per plant ranged from 20 to 38 with a mean of 28.30 pods per plant, whereas in protected plots the range was between 30 and 40 with a mean of 35.69 pods per plant. The difference in number of pods per plant due to adoption of insecticidal spraying was 20.70 per cent.

\section{Number of seeds per pod}

Data from the table 4 and figure 4 indicated that there was a significant difference between number of seeds per pod in protected and unprotected plots during rabi 2017-18. It was observed that in unprotected plots number of seeds per pod ranged from 4 to 6 with a mean of 5.31 seeds per pod, whereas in protected plots the range was between 5 to 8 with a mean of 6.46 seeds per pod. The difference in number of seeds per pod due spraying of insecticides was 17.80 per cent.

\section{Yield loss}

The yield losses caused by sucking pest complex in blackgram was presented in table 5 and graphically depicted in figure 5 which showed that a significantly higher yield was obtained in protected plots i.e. $1028 \mathrm{~kg} \mathrm{ha}^{-1}$, while, comparitively low yield i.e. $759 \mathrm{~kg} \mathrm{ha}^{-1}$ was recorded from unprotected plots. The yield increase in protected plots over unprotected was $269 \mathrm{~kg} \mathrm{ha}^{-1}$ i.e. 35.44 per cent. The avoidable yield loss was 26.16 per cent due to the damage caused by sucking pests in blackgram during rabi 2017-18.

Thus, the results clearly indicated that by spraying of insecticides i.e. monocrotophos
36\% SL and Fipronil 5\% SC at weekly intervals against sucking pests viz., whiteflies, thrips, aphids and leafhoppers in blackgram saved 269 $\mathrm{kg} \mathrm{ha}^{-1}$ pod yield with an avoidable yield loss of 26.16 per cent.

Gupta and Bhattacharya (2008) reported that the annual yield loss due to the insect pests has been at about 30 per cent in blackgram and greengram. Duraimurugan and Tyagi (2014) reported that the avoidable yield losses due to pest complex on different varieties of greengram ranged from 27.03 to 38.06 percent with an average of 32.97 per cent. The avoidable yield losses due to pest complex on different varieties of blackgram ranged from 15.62 to 30.96 per cent with an average of 24.03 per cent.

Abudulai et al., (2012) reported that yield loss ranged between 25.8 and 42.8 per cent in untreated plots, 11.10 and 34.30 per cent in plots that were protected at the vegetative stage, and 5.20 and 11.30 per cent in plots that were protected at the reproductive stage in soybean. Vikranth et al., (2015) reported that the estimated avoidable yield loss due to insect pest infestation in blackgram was 55.20 per cent when sole crop of blackgram was exposed to insect infestation.

Subahsh and Singh (1993) reported that spraying with monocrotophos at $0.04 \%$ after seventeen days after sowing gave maximum leaf area and shoot length in blackgram. Singh (2002) recorded significantly higher values for plant height, number of branches, pod length, pods per plant, yield per plot in protected plots compared to the unprotected plots in greengram.

Dzemo et al., (2010) reported that the application of insecticide, once at flower budding, early podding and pod filling significantly reduced pod and seed damage, resulting in substantial increase in number of pods, pod weight and seed weight per plant, and 
also number of seeds per pod of cowpea compared to the untreated control.

Jat et al., (2017) reported that mean loss in plant height was 15.85 per cent, mean number of pods per plant 20.42 per cent, mean number of seeds per pod 15.76 mean yield per plot 27.10 per cent in unprotected plots against protected plots in blackgram.

\section{Acknowledgements}

My first and most earnest, acknowledgment must go to my guide Dr. C. Narendra Reddy for his Scholastic guidance, unceasing interest, valuable knowledge, technical advice, patient audience. I wish my sincere thanks to $\mathrm{S}$. Ramesh for his cooperation and kindness during my study and I thank all my teachers, friends and university for their cooperation and help during the research programme.

\section{References}

Abudulai, M., Abdulai, B.S., Danial, O.A., Haruna, M., Nicholas, N.D and Baba, I. I. Y. 2012. Yield loss at the different growth stages in soybean due to insect pests in Ghana. Phytopathology and Plant Protection. 45: 1796-1809.

Chandra, U and Rajak, D.C. 2004. Studies on insect pests on urd bean (Vigna mungo). Annals of Plant Protection Sciences. 12(1):213-214.

Duraimurugan, $\mathrm{P}$ and Tyagi, K. 2014. Pest spectra, succession and its yield losses in mungbean and urdbean under changing climatic scenario. Legume Research. 37 (2): $212-222$.

Dzemo, W.D., Niba, A.S and Asiwe, J.A.N. 2010. Effects of insecticide spray application on insect pest infestation and yield of cowpea [Vigna unguiculata (L.) Walp.] in the Transkei, South Africa. African Journal of Biotechnology. 9(11): 1673-1679.

Gupta, G and Bhattacharya, A.K. 2008. Assessing toxicity of post-emergence herbicides to the Spilarctiaobliqua Walker (Lepidoptera: Arctiidae). Journal of Pest Science. 81: 9-15.

Jat, S.K., Lekha and Rana, B.S. 2017. Assessment of quantitative losses due to insect pests of blackgram. Plant Archives. 17(1): 488-490.

Jeswani, L.M and Baldev, B. 1990. Advances in pulse production technology. Publication and information division. Indian Council of Agricultural Research. pp. 190.

Pradhan, S. 1969. Insect Pests of Crops. National Book Trust, New Delhi, India, pp. 80.

Singh, K. 2002. Estimation of losses, management of insect pests of mungbean [Vigna radiata (L.) Wilczek] and determination of economic threshold level against the lycaenid borer (Lampides boeticus L.). Ph.D. thesis submitted to Maharana Pratap University of Agriculture and Technology, Udaipur.

Subash, C and Singh, Y. 1993. Phytotonic and phytotoxic effects of some insecticides in greengram, Vign radiata (1.) Wilczek. Indian Journal of Entomology. 55(2): 140-147.

Vikranth, R.A., Swaminathan Kumar and Singh, D. 2015. Estimation of losses caused by major insect pests of blackgram at different stages of crop growth. Journal of Experimental Zoology, India. 18: 665668.

\section{How to cite this article:}

Malreddy Radhika and Chinthakindi Narendra Reddy. 2018. Estimation of Avoidable Yield Loss Due to Sucking Pest Complex in Blackgram. Int.J.Curr.Microbiol.App.Sci. 7(05): 2403-2410. doi: https://doi.org/10.20546/ijcmas.2018.705.276 